\title{
PARADIGMA KOMUNIKASI ISLAM DALAM MENANGGULANGI TERORISME
}

\author{
Oleh. \\ Aisyah Khumairo \\ Institut Agama Islam Negeri Metro \\ aisyahkhumairo8@gmail.com
}

\begin{abstract}
Islamic communication is one of the most interesting themes to be discussed. Communication and terrorism are two terms that are often aligned by academics and practitioners. Terrorist acts become fluid not only because of the shrewdness of the perpetrators, but also because of intense communication among the various members to prepare all things. In tackling terrorism, Islamic communication that now has a lot of authority, must continue to be implemented properly. The paradigm used as a driver of Islamic communication should also be reviewed to adjust to the present conditions. Communication paradigm becomes important to be discussed because it is the framework of the implementation of Islamic communication in this contemporary era.
\end{abstract}

\section{Keywords: Paradigm, Islamic Communication, Terrorism}

\section{A. PENDAhUlUAN}

Adanya Badan Nasional Penanggulangan Terorisme, Polisi, TNI, dan aparat keamanan lainnya, nampaknya belum juga membuat para teroris jera.Bergabungnya seluruh aparat keamanan dalam melawan terorisme, seharusnya membuat para teroris jera dan bertaubat kembali ke jalan yang benar.Mereka seharusnya memahami bahwa perbuatan yang dilakukannya bukanlah merupakan bagian dari kebaikan.Namun yang terjadi justru para teroris melakukan hal-hal yang lebih ekstrim lagi dalam meneror warga negara Indonesia.Mereka tidak jera dan mereka tidak takut dengan keberadaan siapapun yang ingin menghalangi aksinya.

Hal ini kemungkinan besar akan tetap terus terjadi, karena regenerasi terus dilakukan oleh kelompok teroris di Indonesia.Mereka merekrut para pemuda dan orang-orang dewasa yang labil untuk dijadikan sebagai aktor teror di tempat-tempat yang telah ditentukan.Intensitas perekrutan ini dilakukan setiap saat tanpa memandang latar pendidikannya.Oleh karena itu, tidaklah herat jika jumlah teroris bukan semakin berkurang ataupung habis, tetapi justru tumbuh generasi penerus baru yang lebih cerdas.Kecerdasan dan jumlahgenerasi penerus ini, lambat-laundapat memupuk kesuburan perkembangan teroris di Indonesia. 
Keberadaan teroris di Indonesia, sejatinya bukanlah berita baru yang disiarkan kemarin-kemarin.Keberadaan teroris sebenarnya sudah sejak lama di Indonesia, mereka membangun dan memperkuat jaringan dan anggotanya di Indonesia.Keberadaan mereka kini telah menyebar ke berbagai daerah, agenda mereka ialah untuk menggalang kekuatan secara kuantitas dan pengumpulan dana. Jika hal ini dibiarkan dan tanpa perlawanan dengan intens, maka kekuatan para teroris akan sangat kuat. Hal yang dikhawatirkan ialah kejadian-kejadian teror akan semakin merajalela di Indonesia.

Langkah yang mereka tempuh dalam melakukan regenerasi ialah melalui dua hal, yaitu membangun komunikasi secara langsung dan tidak langsung.Regenerasi yang dilakukan secara langsung artinya mereka mempengaruhi orang, baik muda maupun tua dengan cara face to face. Mereka dirayu dan diiming-imingi harta, jabatan, dan yang paling utama ialah surga.Rayuan ini sangat matang dipersiapkan, karena di dalamnya juga dikutib ayat-ayat al-Qur'an dan hadis yang dipandang sesuai dengan kehendaknya.Komunikasi yang intens terbangun atas dasar strategi-strategi yang sudah dipersiapkan sebelumnya.

Sedangkan regenerasi tidak langsung ini artinya rekrutmen anggota tidak dilakukan secara face to face, tetapi komunikasi dalam rekrutmen terjalin melalui dunia maya.Kecanggihan dunia maya ini dapat memberikan ruang yang besar bagi para teroris untuk menyebarkan konten-konten yang membuat para pembaca tergiur.Tawaran surga yang dilandasi berbagai ayat al-Qur'an telh banyak beredar di dunia maya.Ayat al-Qur'an banyak yang dikutip hanya sebagian, bahkan penafsirannya pun dimonopoli oleh dirinya sendiri tanpa melihat konteks turunnya al-Qur'an.Jadi komunikasi yang dibangun di dunia maya ini sejatinya lebih berbahaya, karena siapapu dengan jumlah berapapu bisa terpengaruh dengan konten-konten ini.

Hal tersebut berdampak besar terhadap kehidupan para pemuda di Indonesia, karena yang seringkali menjadi korban dari konten-konten yang disebar para teroris ini ialah pemuda.Begitu juga bagi warga negara yang lainnya, mereka tampak terganggu dengan kehadiran terorisme di Indonesia.Kehidupan mereka diliputi rasa takut dan saling curinga, baik antar teman, tetangga, sanak-saudara, dan bahkan agama.Mereka merasa tidak aman dan nyaman lagi ketika bepergian, baik jauh maupun dekat.Terorisme yang direpresentasikan dengan pemboman, tidak dapat diprediksi kapan dan di mana bisa terjadi.

Kejadian-kejadian bom yang telah dilakukan di beberapa tempat, menyebabkan tumbangya sejumlah warga negara Indonesia.Rentetan kejadian bom yang terkenal ialah bom Bali, Sarinah, dan di hotel Ritz Carlton, dan bom panci.Kejadian-kejadian ini membuktikan bahwa rekrutmen melalui komunikasi yang intens dapat membuahkan hasil yang signifikan. Doktrinasi yang dilakukan dengan cara offline maupun online sejatinya merupakan komunikasi yang diatur sedemikan rupa untuk meyakinkan seseorang. Maka 
tidak heran jika mereka berani menjadi korban dari pemboman yang dilakukan sendiri.

Hal tersebut perlu ditanggapi serius bukan saja oleh BNPT, TNI, dan Polri, tetapi oleh seluruh warga Indonesia.Indonesia harus membangun suasana yang kondusif, aman, dan nyaman.Indonesia juga perlu membagun komunikasi yang intens dengan siapapun untuk menolak adanya terorisme di Indonesia.Dalam membangun komunikasi yang berkualitas, maka paradigma komunikasi juga harus ada perubahan yang bernuansa Islam toleran.Paradigma baru dalam komunikasi ini sangat diperlukan di tengahtengah mencekamnya terorisme di Indonesia.Paradigma ini pada nantinya bukan saja sebagai landasan temporer dan insidental, tetapi juga bisa menjadi landasan dalam melakukan pergerakan di masa-masa yang akan datang.

Sebuah komunikasi dan penyiaran Islam memerlukan paradigmayang fresh dalam membangun komunikasi yang satu jalur dengan cita-cita agama dan Indonesia, sehingga bisa membuat Indonesia dalam suasana aman dan tentram.Islam sebagai agama yang rahmatan lil 'alamin harus membangun paradigmanya sendiri dengan penuh unsur-unsur kedamaian.Komunikasi Islam yang kini harus digiatkan dan diperluas oleh dunia akademisi dan praktisi, dengan tujuan untuk menebarkan hal-hal yang positif dan mendukung Undang-undang ITE.

Komunikasi merupakan salah satu hal yang pentung dalam penyampaian ide, gagasan, maksud suatu hal kepada pihak lain.Kalangan teroris menggunakan komunikasi sebagai alat untuk mensosialisasikan gagasan-gagasan radikalnya.Sedangkan bagi kalangan akademisi dan praktisi, komunikasi digunakan untuk menolak pandangan-pandangan teroris yang sangat keras.Dalam menolak gagasan kaum teroris, Dengan hal inilah, bangsa Indonesia bisa menghindarkan diri dari berbagai persoalan teroris.

Paradigma baru perlu untuk diamini seluruh bangsa Indonesia, karena dengan persamaan paradigma dalam memberantas teroris, tentu akanmemberikan dampak yang signifikan bagi kenyamanan bangsa Indonesia. Persamaan paradigmadan persepsi ini harus diperkuat, karena tatanan jamaah yang solid akan bisa memberikan pengaruh besar bagi Indonesia.

Kolaborasi antara pemerintah, seperti Badan Nasional Penanggulangan Terorisme, TNI, Polri dan organisasi-organisasi yang konsen dalam hal ini perlu untuk membangun paradigma komunikasi Islam yang ramah.Komunikasi Islam menekankan kepada penyampaian hal-hal yang baik berdasarkan ajaran yang terdapat di dalam al-Qur'an, sunah, para sahabat, tabi' in, dan ulama, serta nilai-nilai budaya lokal.Membangun paradigma mengenai komunikasi Islam, tentunya diharapkan dapat berfungsi dengan baik dalam menanggulangi terorisme. 


\section{B. TERORISME}

Istilah terorisme berasal dari bahasa Inggris to terror, sedangkan dalam bahasa Latin diebut Terrere yang artinya gemetar atau menggetarkan.Istilah terreremerupakan bentuk kata kerja dari kata terrorem, yaiturasa takut yang luar biasa.Istilah terorisme dapat dikatakan segala sesuatu yang dilakukan untuk menimbulkan berbagai ketakutan yang luar biasa pada masyarakat. ${ }^{1}$

Dalam literatur lain, istilah "teroris" dan terorisme berasal dari bahasa Latin terrere, yang berarti membuat gemetar atau menggetarkan. Sebenarnya istilah terorisme adalah sebuah konsep yang diklaim memiliki konotasi sensitif.Hal ini terjadi karena aksi terorisme dapat mengakibatkan timbulnya korban dari warga negara yang tidak berdosa.2Pengertian demikian tidak sepenuhnya bisa disepakati oleh para ahli, namun setidaknya dalam artikel ini dapat memberikan pengertian yang jelas.

Banyaknya kepentingan politik yang mengiringi istilah terorisme, membuat pemahaman tentang terorisme menjadi timpang.Para ahli berbedabeda dalam memberikan pengertian mengenai istilah terorisme sangat terlihat dalam kasus invasi Amerika Serikat ke Irak pada tahun 2003.Pada saat itu AS melegitimasi invasinya ke Irak dengan alasan Irak sebagai teroris yang memiliki senjata canggih pemusnahan masal. ${ }^{3}$

Kendati demikian, pengertian mengenai istilah terorisme yang merupakan perbuatan untuk menimbulkan rasa takut pada orang lain bisa dibilang mewakili representasi dari berbagai tindakan yang dilakukan oleh para kelompok teroris.Pengertian ini bisa diterima dari segi tindakan, sedangkan dalam segi pemikiran masih harus digali dengan lebih dalam.

\section{Rekrutmen Anggota}

Tindakan terorisme yang terjadi di Indonesia sebenarnya sudah diantisipasi oleh pemerintah. Tokoh, lokasi, dan strateginya banyak yang sudah diketahui oleh BNPT, TNI, maupun Polri, sehingga ketika ada kejadian teror bom di beberapa daerah, maka hal tersebut sudah bisa dilacak kesinambungan pelaku dengan jaringannya. Sebagaimana umum diketahui bahwa jaringan teroris ini bukan terdiri dari satu kelompok, tetapi terdiri dari berbagai kelompok berbeda yang meimiliki kesamaan visi dan misi.

${ }^{1}$ Ensiklopedi Pencegahan Terorisme (Jakarta: Badan Nasional Penanggulangan Terorisme, 2016), hlm. 59.

2 Indriyanto Seno Adji, Terorisme dan HAM dalam Terorisme: Tragedi Umat Manusia (Jakarta: O.C. Kaligis \& Associates, 2001), hlm 17.

${ }^{3}$ Namun di sisi lain, banyak negara yang menyatakan bahwa AS lah yang pantas dikatakan negara neroris, karena melakukan invasi tanpa persetjuan dewan keamanan PBB. Abdul Wahid, Sunardi, Muhamad Imam Sidik, Kejahatan Terorisme: Perspektif Agama, HAM dan Hukum (Bandung: PT. Refika Aditama, 2004), hal. 23.

Paradigma Komunikasi Islam Dalam.....

Aisyah Khumaira 
Perbuatan teror yang terjadi di berbagai daerah sejatinya merupakan hal yang sangat merugikan, karena terdapat korban jiwa dan membuat kericuhan.Para pelaku tindakan teror, diketahui adalah orang-orang baru dan usianya masih muda. Ini artinya bahwa dedengkot teroris bukan sebagai eksekutor, tetapi ia terlebih dulu mempersiapkan pemuda untuk menjadi pengantin.Menyiapkan pengantin ini membutuhkan manajemen yang handal, karena mereka harus melakukan dengan cara yang rapi agar tidak dicurigai oleh orang lain.

Hal awal yang dilakukan adalah merekrut anggota untuk dijadikan sebagai pengantin. Kepala Badan Nasional Penanggulangan Teroris Komjen Pol Suhardi Alius menjelaskan ada pergeseran rekrutmen anggota teroris. Awalnya, rekrutmen anggota baru dilakukan dengan tatap muka, namun kini menggunakan jejaring internet atau dengan cara online. ${ }^{4}$ Rekrutmen ini semakin marak dilakukan melalui jalinan komunikasi media sosial. Hal ini merupakan cara kontemporer yang bisa dilakukan tanpa membuang biaya banyak, namun hasilnya cukup signifikan.

\section{Komunikasi Jaringan Teroris}

Jaringan teroris yang kian berkembang, sejatinya mengembangkan komunikasinya bukan hanya melalui perkumpulan seperti orang diskusi, tetapi lebih masif menggunakan media sosial. Aplikasi Facebook, WhatsApp, Telegram, Instagram, dan lain sebagainya dapat digunakan membangun komunikasi dengan mudah oleh jaringan teroris. Kecanggihan yang ditunjukkan dalam berkomunikasi ini ialah tidak ada informasi yang bocor kepada orang lain, bahkan keluarganya sendiri.Kemasan komunikasi ini dibangun di atas sikap yang eksklusif, sehingga sangat terjaga rahasianya.

Kendati banyak aplikasi media sosial yang ada di Indonesia, namun yang massif digunakan untuk menjalin komunikasi ialah Telegram.Hal ini diungkapkan oleh Kapolri Jenderal Tito Karnavian "Cukup massif, karena selama ini fitur telegram banyak keunggulam, di antaranya mampu buat sampai 10.000 member". ${ }^{5}$ Telegram merupakan aplikasi pesan chatting yang bisa digunakan para anggotanya untuk mengirim pesan obrolan rahasia.Telegram juga bisa digunakan untuk membagi gambar, video, share lokasi, transfer dokumen.Telegram dapat dikatakan aplikasi terbaik dari semua aplikasi media sosial, karena telegram ini cepat, tidak ada iklan, ringah, dan gratis.

4http:/ / nasional.kompas.com/read/2017/04/02/22222211/kepala.bnpt.ingatka n.bahaya.rekrutmen.teroris.via.online.

${ }^{5}$ http://www.bbc.com/indonesia/indonesia-40622484

Paradigma Komunikasi Islam Dalam.....

Aisyah Khumaira 


\section{KOMUNIKASI ISLAM}

Komunikasi berasal bahasa latin communis, kemudian dalam bahasa Inggris disebut dengan istilah common, yang artinya sama. ${ }^{6}$ Oleh karenanya dalam berkomunikasi, seseorang berusaha untuk menumbuhkan dan mempengaruhi orang lain agar timbul persamaan sikap dalam suatu perkara.Dengan demikian, komunikasi bisa dipahami sebagai proses menghubungi dan bisa juga dikatakan bahwa komunikasi merupakan proses penyampaian pesan oleh komunikator kepada komunikan melalui prantara media agar dapat menimbulkan hasil yang diharapkan.Dalam komunikasi, hampir dipastikan ada tiga unsur yang saling berkaitan, yaitu sumber, pesan, dan sasaran. ${ }^{7}$

Komunikasi juga bisa diartikan interaksi antar manusia yang saling mempengaruhi, baik disengaja maupun tidak disengaja.Tidak ada batasan pula mengenai komunikasi ini menggunakan bahasa verbal maupun non-verbal seperti melalui lukisan, seni, teknologi, dan ekspresi wajah. ${ }^{8}$ Jadi komunikasi bisa terjalin antar manusia terjalin jika ada pesan yang disampaikan dan adalah pengaruh yang menonjol.

Istilah Komunikas dalam Islam dikenal dengan istilah ittishal (إنصال) yang berasal dari kata washala yang berarti sampaikan. Misalkan dalam alQur'an surat al-Qashash ayat 51:

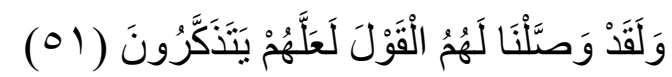

"dan Sesungguhnya telah Kami turunkan berturut-turut Perkataan ini (Al Quran) kepada mereka agar mereka mendapat pelajaran." ${ }^{9}$

Komunikasi secara intens dilakukan oleh Allah SWT kepada Nabi Muhammad SAW, dengan menyampaikan al-Qur'an secara berangsurangsur.Komunikasi ini terjalin dengan intens karena misi pesan yang disampaikan oleh Allah SWT kepada Nabi Muhammad SAW untuk mendukung misi kerasulan, yaitu menyempurnakan akhlak umat. Penyempurnaan akhlak akan tertata apabila ada pedoman yang utuh dari Nabi Muhammad SAW. Pedoman inilah yang dinamakan al-Qur'an.Jadi dari

\section{7}

${ }^{6}$ Rosmawaty, Mengenal Ilmu Komunikasi(Bandung: WidyaPadjajaran, 2010), hlm.

${ }^{7}$ Apriadi Tamburaka, Agenda Setting Media Massa(Jakarta: RajaGrafindo Persada2013), hlm. 7.

8 Haffied Cangara, Pengantar Ilmu Komunikasi (Jakarta: Raja Grafindo Persada, 1998), hlm. 19.

${ }^{9}$ Allah s.w.t. menurunkan Al Quran ini bahagian demi bahagian supaya orang kafir Mekah dapat memahaminya dengan baik dan supaya mereka beriman dengannya.

Paradigma Komunikasi Islam Dalam.....

Aisyah Khumaira 
komunikasi yang intens, dapat tercipta sebuah tatanan yang bagus, karena bisa saling mempengaruhi.

\section{ETIKA KOMUNIKASI ISLAM}

Komunikasi yang dibangun berdasarkan ajaran Islam, harus memiliki etika yang baik sebagaiaman ajaran Islam. Etika ialah ilmu tentang apa yang baik dan buruk, tentang hak dan kewajiban moral.Etika juga bisa dikatakan sebagai asas yang berkenaan dengan akhlak, atau nilai yang ada mengenai benar dan salahnya suatu tatanan masyarakat. ${ }^{10}$ Dalam berkomunikasi, etika seorang muslimharus ditonkolkan sebagai jati diri seorang muslim.

Komunikasi yang baik dalam Islam ialah jalinan interaksi yang sesuai dengan kaidah-kaidah agama.Ukuran baiknya berasal dari nilai-nilai yang terkandung dalam al-Qur'an dan hadis, sehingga dalam Islam istilah etika disebut dengan akhlak.Oleh karena itu, umat Islam harus berkomunikasi dengan akhlak yang diajarkan dalam Islam sendiri. ${ }^{11}$ interaksinya harus dibangun dengan baik, begitu juga hal yang disampaikan juga harus sesuai dengan ajaran Islam. Jangan sampai komunikasi yang terjalin justru merusak tatanan kebaikan yang sudah ada di masyarakat. berikut:

Etika komunikasi dalam Islam dijelaskan di dalam al-Qu'an sebagai

"dan hendaklah takut kepada Allah SWT orang-orang yang seandainya meninggalkan dibelakang mereka anak-anak yang lemah, yang mereka khawatir terhadap (kesejahteraan) mereka. oleh sebab itu hendaklah mereka bertakwa kepada Allah SWT dan hendaklah mereka mengucapkan Perkataan yang benar.(An-Nisa' [4]: 9).

Dalam ayat ini dijelaskan bahwasannya jangan sampai umat Islam tidak memberikan pendidikan yang baik bagi anaknya, sehingga anak-anaknya lemah dalam berbagai hal.Pendidikan yang baik bisa tercapai apabila komunikasi yang dibangun baik pula, yang dalam al-Qur'an disebut harus mengucapkan perkataan yang benar atau menyampaikan hal-hal yang benar terhadap anak-anak.Jangan sampai ada hal-hal negatif yang disampaikan kepada anak, sehingga pada nantinya bisa membuat anak-anaknya lemah.

Komunikasi yang buruk juga akan menimbulkan lemahnya anak di masa depan.Komunikasi buruk ini digambarkan dengan kata-kata yang kasar dan tidak berperikemanusiaan.Kata-kata kasar ini pada nantinya bisa membuat anak lemah untuk menjadi orang yang berkata baik.Kata-kata yang masuk hlm. 237.

${ }^{10}$ Dep. Pendidikan dan kebudayaan, Kamus Bahasa Indonesia(Balai Pustaka, 1990),

${ }^{11}$ Mafri Amir, Etika Komunikasi Massa dalam Pandangan Islam (Ciputat, Logos Wacana Ilmu, 1999),hlm. 35-36

Paradigma Komunikasi Islam Dalam.....

Aisyah Khumaira 
dalam dirinya adalah kasar, sehingga besar kemungkinan kata-kata yang anakanak lontarkan juga kasar.

Perkataan yang bisa membekas pada orang lain bisa dilakukan, namun tidak mudah bagi orang-orang yang belum mengetahui cara berkomunikasi dengan baik. Di sini Islam mengajarkan bahwa dalam berkomunikasi harus ada sesuatu yang bisa membuat orang lain memperhatikan pesan yang disampaikan, dan bahkan kalau bisa membekas terus di dalam diri seseorang.

\section{E. CIRI KOMUNIKASI ISLAM}

Komunikasi dalam Islam sebenarnya memiliki kessamaan ciri-ciri dengan komunikasi secara umum, seperti proses, model, dan pengaruh informasinya. Sekalipun sama, namun perbedaannya terdapat pada latar belakang filosofinya. Komunikasi Islam memiliki ciri khas yang sangat membedakan dengan komunikasi pada umumnya.Komunikasi Islam memiliki filosofi al-Qur'an dan hadis, kemudia seluruh aspek-aspek dalam komunikasi juga dikaitkan dengan al-Qur'an dan hadis.Komunikasi dalam Islam ditekankan pada penyebaran atau penyampaian pesan atau Oleh karena itu informasi kepada orang lain tentang hal-hal yang dilarang dan diperintahkan Allah SWT . Etikanya juga hampir sama dengan komunkasi secara umum, namun yang membedakan ialah pada sanksi dan pahalanya. ${ }^{12}$

Ciri khas yang mengandung al-Qur'an dan hadis inilah tidak terdapat pada komunikasi secara umum.Kandungan kedua sumber ajaran Islam menjadikan komunikasi semakin memiliki nilai tinggi di mata manusia.Komunikasi dalam Islam sealu memuat ajaran dasar Islam, misalkan sejak zaman Nabi Adam hingga Nabi Mumammad, komunikasi yang digunakan ketika berhadapan dengan umatnya selalu mengandung ajaran Allah SWT .

Ciri khas dalam pendekatan komunikasi Islam ialah dengan kasih sayang, hikmah, dan persuasif.Pendekatan ini ialah pendekatan yang paling tinggi nilainya, sehingga pada nantinya bisa membuat pesan-pesan yang disampaikan membekas dalam hati seseorang.Tujuan dari pendekatan ini ialah agar orang lain merubah sikapnya sesuai dengan apa yang dikatakan atau sesuatu yang dikomunikasikan sebelumnya. Tujuan tentang perubahan sikap ini sama halnya seperti tujuan diutusnya Nabi Muhammad SAW, yaitu untuk menyempurnakan akhlak manusia.

\section{F. PARADIGMA KOMUNIKASI DAN PENYIARAN ISLAM DALAM MENANGGULANGI TERORISME}

Paradigma dalam berkomunikasi harus ditelaah kembali untuk mengevaluasi berbagai hal yang masih dianggap kurang begitu memadai di

12 Andi Abdul Muis, Komunikasi Islam (Bandung: Remaja Rosdakarya, 2001), hlm. 5.

Paradigma Komunikasi Islam Dalam.....

Aisyah Khumaira 
era kontemporer ini.Paradigma komunikasi yang banyak menggunakan media masa ataupun secara verbal, kini mulai terlihat pergeserannya.Semua paradigma komunikasi dalam Islam ini hanya satu arah dan hanya secara verbal.Misalkan pada zaman Nabi Muhammad SAW, semua umat Islam selalu menanyakan tentang apapun yang tidak diketahuinya dan Nabi Muhammad SAW memberikan informasi yang benar.Kemudian setelah Nabi wafat, komunikasi menjadi tidak satu arah, tetapi lebih heterogen.Siapa saja bisa berpendapat, hal tersebut dicontohkan dengan penentuan khalifah.

Transisi kepemimpinan pada zaman Khulafa' Rasyidin dan dinastidinasti Islam memberikan potret yang positif.Sisi positifnya ialah menunjukkan bahwa jumlah umat Islam semakin banyak, ini artinya komunikasi dalam menyiarkan Islam yang dibangun semenjak Nabi telah berhasil membuat perubahan sikap masyarakat.Pendekatan komunikasi dengankasih sayang dan hikmah, membuat banyak orang Yahudi dan Nasrani tercengang.Nabi Muhammad SAW menyampaikan risalah bukan saja secara verbal, tatapi juga secara non-verbal.

Ternyata yang sangat diakui dakwah Nabi Muhammad SAW berhasil justru dengan cara komunikasi non-verbal, yaitu akhlak Nabi Muhammad SAW .Orang-orang non muslimsangat mengapresiasi dan terkagum-kagum dengan akhlak Nabi Muhammad SAW . Tidak mudah terpancing oleh provokasi rendahan, bahkan pernah Nabi Muhammad SAW dianiaya sampai berdarah-darah, tetapi Nabi Muhammad SAW tidak membalas perbuatan orang yang menganiaya.Justru Nabi Muhammad SAW dengan lapang dada mendoakan penganiaya agar cepat sadar.

\section{G. TRANSISI PARADIGMA DI ERA KONTEMPORER DALAM MENANGULANGI TERORISME}

Abdul Karim menggambarkan bahwa terdapat perubahan paradigma dalam menjalin komunikasi.Selama ini komunikasi Islam hanya berkutat pada konsep dan metode dalam menyampaikan berbagai hal yang berkaitan dengan komunikasi.Padahal hal yang jarang disadari ialah bahwa dalam membangun komunikasi ini diperlukan paradigma yang utuh.Paradigma komunikasi Islam menurut Abdul Karimharus berorientasi pada peningkatan skillsumber daya manusia (SDM).Komunikasi Islam bukan hanya mengandalkan hal-hal yang praktis, tetapi juga harus membangun kecerdasan pada tingkat teknis. ${ }^{13}$

Padarigma komunikasi Islam sejatinya memang harus memperhatikan skill sumber daya manusia agar mereka bisa mengelola media-media dan pesan-pesan menjadi akurat.Perkembangan teknologi dan Informasi di era

${ }^{13}$ Abdul Karim, Paradigma Baru Komunikasi dan Penyiaran Islam (Sebuah Upaya dalam Merekonstruksi Realitas Media Massa), At-Tabsyir Jurnal Komunikasi Penyiaran Islam, Vol. 5 No. 2 Oktober 2015, hlm. 186.

Paradigma Komunikasi Islam Dalam.....

Aisyah Khumaira 
komtemporer ini diakui sangat pesat.Jaringan internet semakin luas dan media sosial semakin banyak, sehingga membuat dunia ini semakin terbuka.

Oleh karena itu komunikasi Islam harus memperhatikan skill para SDM nya untuk bisa mengelola berbagai situs internet dan media sosial untuk bisa menyampaikan pesan-pesan kepada para komunikan dengan baik.Para pelaku teroris yang bergerak di bidang kejahatan saja mampu melakukan dengan baik.Jika hal ini tidak diimbangi dengan pengelolaan komunikasi dengan baik, maka bisa jadi Islam terus-terusan menjadi objek hujatan sebagai agama teroris.

Skill sumber daya manusia di erat kontemporer ini memang sudah banyak yang canggih, namun masih kurang dalam mengelola media dan pesan-pesan komunikasi dengan baik.Transisi ini memerlukan waktu yang cukup lama, agar sumber daya manusia dapat terhimpun dengan sempurna.Dalam kenyataannya, SDM bangsa Indonesia saat ini sangat membutuhkan pengetahuan mengenai komunikasi Islam sendiri, karena masih banyak yang tidak beretika dalam menggunakan media komunikasi.

Jika oraganisasi-organisasi media yang dikelola oleh umat Islam dapat secara aktif mengingat Tuhan, maka melalui kontrol pengamalan dan profesionalitas akan menyebarluaskan informasi secara benar dan positif. ${ }^{14} \mathrm{Hal}$ ini penting untuk ditingkatkan, karena media yang saat ini mengajak untuk mengingat Tuhan harus terus digalakkan.

\section{Menanggulangi Terorisme}

Dengan paradigma yang sesuai dengan konteks kekinian dan sebagai respon dari gerakan terorisme, dengan mudah bisa mengimbangi gerakannya.Jika paradigma yang ditetapkan ialah berorientasi kepada peningkatan skill sumber daya manusia, maka hal tersebut dianggap tepat.Umat Islam secara keseluruhan dipersiapkan untuk bisa menjadi komunikator secara massif untuk mengelola media offline maupun online dalam menebarkan kebaikan dan jalan yang benar.

Jika para kelompok teroris menebarkan istilah jihad sebagai gerakan terorisme, maka umat Islam yang sudah menguasai skill komunikasi Islam ini harus meluruskan berbagai hal yang berkaitan dengan jihad. Jihad dalam Islam bukanlah diinterpretasikan dengan kekerasan dan perang semata, tetapi jihad dalam Islam bisa dikatakan sebagai perjuangan melawan kejahatan dalam diri sendiri agar menjadi umat yang bermoral, menyebarkan dan membela Islam, dan menciptakan sebuah keadilan masyarakat melalui dakwah. ${ }^{15}$

Dengan memahami dan menjelaskan berbagai makna jihad dalam berbagai penafsiran sepanjang sejarah muslimkepada khalayak masyarakat, maka dapat memungkinkan umat Islam untuk bisa membedakan antara

14S. Shaukat Ali, Foundations for Communication in The Qur'an and Sunnah (The American Journal of Islamic Sciences), hlm. 22.

${ }^{15}$ John L. Esposito, Unholy War (Yogyakarta: LKiS, 2002), hlm. 35.

Paradigma Komunikasi Islam Dalam.....

Aisyah Khumaira 
organisasi teroris atau organisasi lain yang bukan teroris.16Pemahaman seseorang tergantung sejauh mana dia membaca dan bercengkerama dengan orang yang lebih memahami.

Penanggulangan terorisme dalam paradigma baru komunikasi Islam ini lebih bervariasi.Jika para zaman dulu Nabi Muhammad SAW dikagumi dengan akhlaknya, maka umat Islam sekarang harus mengembangkan skill akhlaknya agar menjadi lebih baik.Selain itu, umat Islam juga bisa memperbanyak atribut yang menjelaskan jalan Islam yang benar.

Jadi ada kesinambungan yang bisa dilakukan, yaitu menanggulangi secara tatap muka maupun melalui dunia maya.Keduanya jarus mengajak masyarakat luas untuk bersama-sama memproduksi pesan yang positif. Sumber daya manusia ini harus dikembangkan potensinya untuk memproduksi pesan-pesan yang positif, sehingga bisa mengajak orang lain juga memproduksi pesan positif.

Produksi pesan yang positif bisa terlaksana jika penelitian-penelitian berbagai literatur maupun lapangan harus dikembangkan.Penelitian mengenai pencegahan tindakan terorisme melalui berbagai macam pendekatan bisa menjadi keuntungan dan memberikan kemanfaatan yang nyata.Penelitianpenelitian ini bisa memperkuat analisis dan komunikasi Islam dalam mengemas pesan-pesan perdamaian kepada masyarakat.

Komunikasi Islam bisa dengan intens melawan komunikasi terorisme selama umat Islm tetap terus meregenerasi para ahli dalam bidang komunikasi, pesan dan pelaksananya.Hal ini harus tetap terus dilakukan, agar umat Islam tidak kalah dalam mengantisipasi dan melindungi masyarakat dari berbagai komunikasi yang merugikan diri sendiri maupun negara.

\section{H. KESIMPULAN}

Berkembangnya terorisme di Indonesia tidak lepas dari rekrutmen anggota dan perluasan wilayah operasi serta dukungan dana yang kuat.Hal ini menjadikan negara Indonesia pasang kuda-kuda, andaikata para teroris bergerak, maka seluruh masyarakat Indonesia bisa bergerak secepat mungkin untuk menanggulanginya dengan intens.Teroris bukan hanya musu satu orang, tetapi musuh bersama, baik individu maupun kelompok.

Komunikasi yang dibangun oleh kelompok teroris banyak memberikan efek kepada warga Indonesia.Tidak sedikit yang menjadi korban dari masifnya strategi komunikasi ini.Media sosial menjadi media yang massif digunakan oleh kelompok teroris dalam membangun komunikasi dengan orang-orang yang dijadikan sebagai objek rekrutan.Kemudian dalam menjalin jaringan seluruh anggota teroris, mereka menggunakan media telegram.Media ini

16Ibid.,hlm. 36.

Paradigma Komunikasi Islam Dalam.....

Aisyah Khumaira 
menjadi alternatif komunikasi, karena memiliki berbagai kelebihan, yang salah satunya ialah jumlah anggotanya dalam telegram bisa mencapai 10.000 .

Paradigma komunikasi Islam kini tidak hanya berorientasi kepada pendekatan dan metode komunikasi Islam.Untuk menanggulangi terorisme, maka paradigma komunikasi saat ini ialah berorientasi pengembangan skill sumber daya manusia.Tujuannya ialah untuk meningkatkan profesionalitas dalam mengelola media-media komunikasi Islam untuk melawan komunikasi yang dibangun oleh para kelompok teroris.

\section{DAFTAR PUSTAKA}

Adji, Indriyanto Seno, Terorisme dan HAM dalam Terorisme: Tragedi Umat Manusia, Jakarta: O.C. Kaligis \& Associates, 2001.

Ali, S. Shaukat, Foundations for Communication in The Qur'an and Sunnah, The American Journal of Islamic Sciences.

Amir, Mafri, Etika Komunikasi Massa dalam Pandangan Islam, Ciputat: Logos Wacana Ilmu, 1999.

Cangara, Haffied, Pengantar Ilmu Komunikasi, Jakarta: Raja Grafindo Persada, 1998.

Dep. Pendidikan dan kebudayaan, Kamus Bahasa Indonesia, Balai Pustaka, 1990.

Ensiklopedi Pencegahan Terorisme (Jakarta: Badan Nasional Penanggulangan Terorisme, 2016), hlm. 59.

Esposito, John L., Unholy War, Yogyakarta: LKiS, 2002.

Karim, Abdul, Paradigma Baru Komunikasi dan Penyiaran Islam (Sebuah Upaya dalam Merekonstruksi Realitas Media Massa), At-Tabsyir Jurnal Komunikasi Penyiaran Islam, Vol. 5 No. 2 Oktober 2015.

Muis, Andi Abdul, Komunikasi Islam, Bandung: Remaja Rosdakarya, 2001.

Rosmawaty, Mengenal Ilmu Komunikasi, Bandung: Widya Padjajaran, 2010.

Tamburaka, Apriadi, Agenda Setting Media Massa, Jakarta: Raja Grafindo Persada 2013.

Wahid, Abdul,dkk.,Kejahatan Terorisme: Perspektif Agama, HAM dan Hukum, Bandung: PT. Refika Aditama, 2004.

\section{WEB:}

http:/ / nasional.kompas.com/read/2017/04/02/22222211/kepala.bnpt.ingatk an.bahaya.rekrutmen.teroris.via.online.

http:/ / www.bbc.com/indonesia/indonesia-40622484 